\title{
Synthesis and Characterization of New Polymeric Chelates Derived from Modified Amberlite IR P69 Resin with $\mathrm{Cr}(\mathrm{III}), \mathrm{Co}(\mathrm{II}), \mathrm{Ni}$ (II) and $\mathrm{Cu}(\mathrm{II})$ Ions.
}

\author{
${ }^{1}$ Mahmoud N. al-jibouri and Taghreed M.Musa ${ }^{2}$ \\ Chemistry department,college of science, al-Mustansiriya university,Baghdad-Iraq
}

\begin{abstract}
:
The Amberlite IR P69 was modified, in a two steps process with new Schiff base (HL) derived from 2-picolyl amine and 2-mercapto-4-methyl-benzyaldehyde. The new modified resin and its polymeric chelates with $\mathrm{Cr}$ (III), Co,Ni and $\mathrm{Cu}$ (II) have been isolated in the solid states and fully characterized on the basis of $\mathrm{H}^{13}{ }^{13} \mathrm{C}$ NMR,FTIR and UV-Visible spectroscopy. Furthermore the magnetic moments and molar conductance of their solutions in DMSO were recorded to investigate the stereo chemical structures of the prepared metal polymers. The results obtained from elemental analyses and the spectral measurements have deduced the coordination of nitrogen and sulphur atoms of Schiff base moiety to Amberlite IR P69 to the selected metal ions, as well as these data in communicated with thermal and magnetic susceptibilities measurements have confirmed the thermal stability and octahedral geometries for Cr III complex, tetrahedral symmetry for Co IIandsqure planner for NiII and Cu(II )polymeric metal chelates.
\end{abstract}

Key words:Amberliteresins, chelating properties of resins, 2-picoline Schiff bases.

\section{Introduction:}

The continual release of metal contaminants into the natural environment from waste streams, atmospheric emissions, combustion of fossil fuels, and urban habitation has led to environmental awareness and read to develop analytical methods for selective separation of heavy metal ions. The potential of chelating resin for separation of toxic metals has been very well established ${ }^{(1-3)}$. Amberlite X-A180 and Amberlite IR P 69 modified with azo derivative ${ }^{(4-6)}$ have been found useful for removing of heavy metal in trace levels. Azothiopyrine sulphonic acid ${ }^{(7)}$ has been incorporated into an anion- exchange for uptake of mercury and cadmium ions from aqueous solutions. Metal containing polymers show many potential applications as functional materials with desirable chemical and physical properties, catalytic activities ${ }^{(8)}$, and models for bioinorganic systems ${ }^{(9)}$. The synthesized novel Amberlite XA-D resin incorporated with hydroquinone for separation and determination of derived from 2-picolyl anion ${ }^{(9)}$ has applications for complexation of some of heavy metal ions, and it was pointed out the nitrogen atoms of $\mathrm{C}=\mathrm{N}$ pyridine ring and adjacent phenolic $-\mathrm{OH}$ group suitable for chelation with heavy metal ions ${ }^{(10)}$. New ways to detect and regularly follow the toxic organic compounds are being searched ${ }^{(11)}$. By this purpose, polymeric ligands are synthesized by modifying present synthetic and natural polymers with functional groups which have different donor atoms ${ }^{(12-13)}$. The parts capable in forming complexes are functional groups as $-\mathrm{OH},-\mathrm{C}=\mathrm{N} ., \mathrm{C}=\mathrm{S},-\mathrm{NH} 2$ and $-\mathrm{SCN}^{-(14)}$. The preparation of new chelating resins by using Amberlite XAD-16 and some chelating agents have been performed by some researchers ${ }^{\cdot(15)}$ Lee and co-workers synthesized a new chelating resin by using Amberlite XAD-16 and 4-(2thiazolylazo) resorcinol. They investigated the adsorption properties of the new resin. Lee and coworkers ${ }^{(16)}$ synthesized two different chelating resins by using 4-(2-thiazolylazo) resorcinol and 1-(2thiazolylazo)-2-naphthol as chelating agent and XAD-16 as support for the preconcentration of trace metal ions ${ }^{(17)}$.In the present work, a chelating resin was synthesized by coupling new azoitized-2-picoline on Amberlite IR-69 and characterized. The chelating properties of the modified resin have adopted with $\mathrm{Cr}(\mathrm{III}), \mathrm{Co}(\mathrm{II}), \mathrm{Ni}(\mathrm{II})$ and $\mathrm{Cu}(\mathrm{II})$ ions on the basis of following the IR and UV-visible spectral techniques as well as the optimal analytical conditions including $\mathrm{pH}$, resin amounts, and initial concentration of metal effects were also investigated.

\section{1-Reagents}

\section{Experimental}

Amberlite IR P 69 resin (mesh size 16-45mm, 98\% divinyl benzene by weight) in acidic form was obtained from Aldrich. Metal Chlorides of $\mathrm{Co}(\mathrm{II}), \mathrm{Ni}(\mathrm{II}), \mathrm{Cu}(\mathrm{II})$ and $\mathrm{Cr}(\mathrm{III})$ have purchased from B.D.H. (England). The solvents were used without purification. The Schiff base of 2-Picolyle amine and 4-methyl-2mercapto-benzaldehyde, has prepared according to method published in literature ${ }^{(18)}$, Scheme (1): 
<smiles>Cc1ccc(C#CN=Cc2ccccn2)c(S)c1</smiles>

Scheme(1)-synthesis of HL Schiff base

\section{2: Preparation of modified resin:}

Cationic resin of Amberlite-IR P69 resin with $-\mathrm{SO}_{3} \mathrm{H}$ group , was treated separately $(3.00 \mathrm{~g}) .(10 \mathrm{ml})$ of conc. $\mathrm{HCl}$ with concentrated $\mathrm{HCl}(10 \mathrm{ml})$ washed with deionized water $(20 \mathrm{ml}$.) then modification , $10 \mathrm{ml}$ of conc. $\mathrm{HNO}_{3}$ and $25 \mathrm{ml}$ of $\mathrm{H}_{2} \mathrm{SO}_{4}$ were added to $3 \mathrm{~g}$ of resin and the mixture was stirred, cooled and filtered then washed with water and ethanol until neutralization. The residue was treated with $(0.3 \mathrm{~g})$ of $\mathrm{SnCl}_{2}$ and sodium bicarbonate $\mathrm{NaHCO}_{3}(9.5 \mathrm{~g})$ in $50 \%$ ethanol and refluxed for 40 minutes. The amino resin was first, treated with $2 \mathrm{M} \mathrm{HCl}$ and finally washed with distilled water. It was suspended in $250 \mathrm{ml}$ of ice water and reacted with $1 \mathrm{M}$ $\mathrm{HCl}$ and $10.12 \mathrm{~g}$ of $\mathrm{NaNO}_{2}$ until a pale blue colored with starch iodide paper was formed. The diazotized resin was washed with ice water and reacted with $(8 \mathrm{~g})$ of $(\mathrm{HL})$ Schiff base and sodium hydroxide $(90 \mathrm{ml}, 5 \%)$ at $-5^{\circ} \mathrm{C}$ with added with stirring and continued until brown colored, precipitate formed, filtered, washed with distilled water, than dried in oven $\left(60-70{ }^{\circ} \mathrm{C}\right)$.

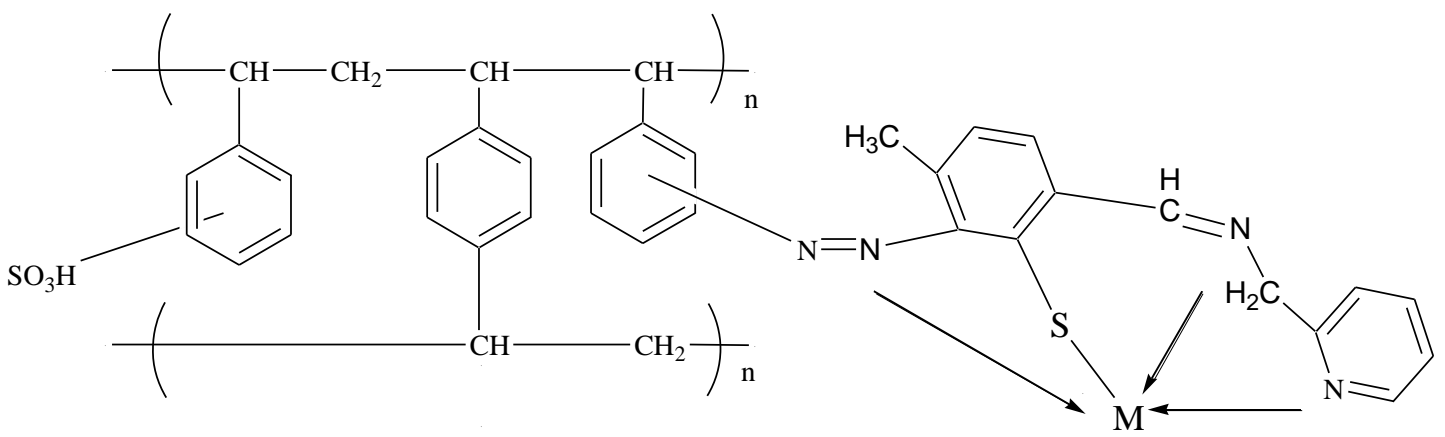

Scheme(2) coordination patterns of Amberlite with $\mathrm{Cr}(\mathrm{III}), \mathrm{Co}(\mathrm{II}), \mathrm{Ni}(\mathrm{II})$ and $\mathrm{Cu}(\mathrm{II})$ ligand.

\section{3-Identification of Schiff base (HL) and modified Amberlite IR P 69 resin}

The infrared spectra of Schiff (HL), modified resin and its polymeric metal chelates were recorded on Shimadzu. 160C Spectrometer in the $(4000-600) \mathrm{cm}^{-1}$ region. The ${ }^{1} \mathrm{H}$ NMR and $13 \mathrm{C}$ NMR spectra were recorded in $\mathrm{CDCl}_{3}$ with TMS as the internal standard, using a Bruker wide bore Avance $300 \mathrm{NMR}$ spectrometer.The electronic absorption spectra of Schiff base (HL) and solutions of polymeric metal chelates in DMSO (spectroscopic grade) were recorded on Shimadzu double beam spectrophotometer in the range of 200-900nm. The magnetic moments of the polymeric metal complexes of modified resin were measured on Bruker Magnetic balance using Faraday method ${ }^{(19)}$. As well as the thermal stability of polymeric metal complexes has recorded for chromium(III)and copper(II) under $\mathrm{N}_{2}$ atmosphere in the range of heating $30-700 \mathrm{C}^{0}$ on Perkin Elmer TGA 4000 at Ibn-cina general company(Baghdad).

\section{1: General:}

\section{Result and Discussion:}

Modified Amberlite IR P69 resin with Schiff base (HL) is brown in colored. The color of the resin changed up on chelating with solutions of metal ions under study $\left(\mathrm{Cr}^{+3}, \mathrm{Co}^{+2}, \mathrm{Ni}^{+2}\right.$ and $\left.\mathrm{Cu}^{+2}\right)$ to green for octahedral $\mathrm{Cr}$ (III). Amber lite, Olive for square planner of $\mathrm{Co}(\mathrm{II})$ and $\mathrm{Ni}(\mathrm{II})$, and pale red for octahedral $\mathrm{Cu}(\mathrm{II})$ ,chelate respectively. This suggests that the chelating of modified resin with Schiff base of 2-picoly-(4-methylbenzimine)-thiophenol proceeds strongly contributions to the adsorption process .

\subsection{Elemental analysis:}

Elemental analysis of the salicyldimine -2-picolyl amine (HL) and its metal complexes with modified resin of Amber lite IR P 69 gave almost the same elemental ratio which is well agree with expected formula, Table(1). 
Table (1): physical properties of the prepared compounds and Elemental analysis data of Ambar-L and their complexes

\begin{tabular}{|c|c|c|c|c|c|c|c|c|}
\hline \multirow{2}{*}{ Compounds } & \multirow[t]{2}{*}{ M.wt } & \multirow[t]{2}{*}{ M.P. ${ }^{\circ} \mathbf{C}$} & \multirow[t]{2}{*}{ Colour } & \multicolumn{5}{|c|}{ Found(Calcd)\% } \\
\hline & & & & $\mathrm{C} \%$ & H\% & N\% & S\% & Metal \\
\hline \multirow[t]{2}{*}{$\mathrm{HL}$} & \multirow[t]{2}{*}{$229 . .32$} & \multirow[t]{2}{*}{$175-177$} & \multirow[t]{2}{*}{ Dark yello } & 67.01 & 4.87 & 12.97 & 12.65 & - \\
\hline & & & & (68.09) & $(5.71)$ & $(12.22)$ & (13.98) & - \\
\hline \multirow[t]{2}{*}{ Ambarlite } & \multirow[t]{2}{*}{690.92} & \multirow[t]{2}{*}{$>250$} & \multirow[t]{2}{*}{ Brown } & 68.53 & 5.00 & 8.14 & 8.71 & \\
\hline & & & & (69.53) & $(6.13)$ & $(8.11)$ & $(9.28)$ & - \\
\hline \multirow[t]{2}{*}{$\mathrm{Cr}(\mathrm{Am}) \mathrm{Cl}_{2}$} & \multirow[t]{2}{*}{812.81} & \multirow[t]{2}{*}{$>340$} & \multirow[t]{2}{*}{ Dark Gree } & 58.20 & 4.89 & 6.97 & 6.56 & 6.01 \\
\hline & & & & (59.11) & $(5.08)$ & $(6.89)$ & $(7.89)$ & $(6.40)$ \\
\hline \multirow[t]{2}{*}[\mathrm{Co}(\mathrm{Am})\mathrm{Cl}]{} & \multirow[t]{2}{*}{799.3} & \multirow[t]{2}{*}{$>302$} & \multirow[t]{2}{*}{ Dark Brov } & 60.21 & 5.98 & 17.67 & 7.87 & 6.81 \\
\hline & & & & (61.61) & $(5.50)$ & (17.01) & $(8.02)$ & (7.37) \\
\hline \multirow[t]{2}{*}[\mathrm{Ni}(\mathrm{Am})\mathrm{Cl}]{} & \multirow[t]{2}{*}{799.09} & \multirow[t]{2}{*}{$>305$} & \multirow[t]{2}{*}{ Brown } & 59.99 & 5.93 & 18.23 & 7.69 & 6.94 \\
\hline & & & & (61.62) & $(5.56)$ & $(7.10)$ & $(8.03)$ & $(7.35)$ \\
\hline \multirow[b]{2}{*}[\mathrm{Cu}(\mathrm{Am})\mathrm{Cl}]{} & \multirow[t]{2}{*}{803.9} & \multirow[t]{2}{*}{$>310$} & \multirow[t]{2}{*}{ Brown } & 60.11 & 5.02 & 7.11 & 7.43 & 7.32 \\
\hline & & & & $(61.26)$ & $(5.52)$ & $(6.97)$ & $(7.98)$ & $(7.90)$ \\
\hline
\end{tabular}

Where $\mathrm{Am}=\mathrm{C}_{41} \mathrm{H}_{44} \mathrm{~N}_{4} \mathrm{O}_{3} \mathrm{~S}_{2}$ it is the repeated unit of modified Ambarlite

\section{3: NMR analysis}

:

The resonance of protons of (HL) in $\mathrm{CDCl}_{3}$ was shown in figure (1). The absorptions in the downfield regions $11.3,8-9.3 \mathrm{ppm}$ may be assigned to proton of $-\mathrm{SH}$ and isomethine $-\mathrm{CH}=\mathrm{N}$ groups respectively ${ }^{(20)}$.As well as the aromatic and pyridine protons Ar-H were recorded as chemical shifts in the regions 7.1-8.4ppm, whereas the resonance of $-\mathrm{CH}_{3}-\mathrm{CH}_{2}-\mathrm{CH}$, and $\mathrm{CH}_{2}-\mathrm{N}$ groups were absorbed in the regions 2.36 and 5.0ppm due to of effect of electron with drawing $\mathrm{N}$ : atom directly attached to $\mathrm{N}=\mathrm{CH}$ and pyridine moiety ${ }^{(21)}$. As well as , figure (2) shows ${ }^{13} \mathrm{C}$ NMR of (HL) in $\mathrm{CDCl}_{3}$, which displays the absorption that agree with numbers of carbon atoms in the expected structure .

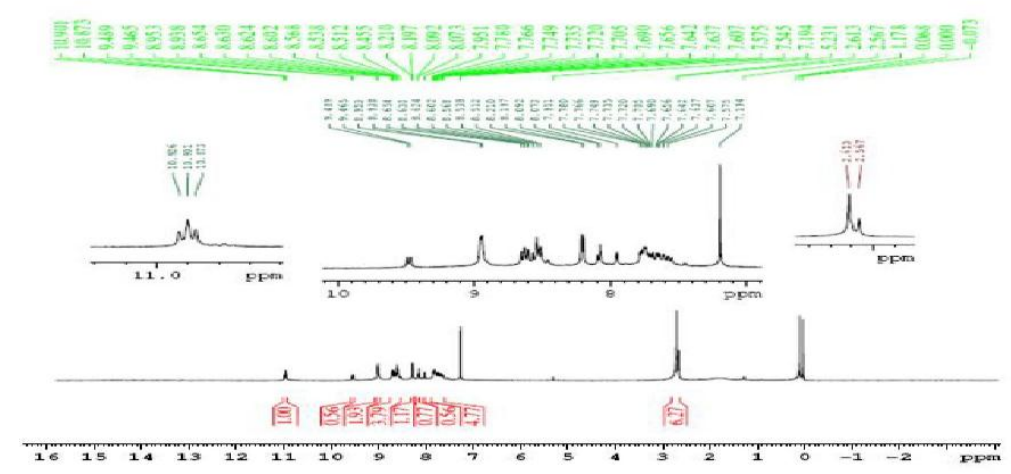

Figure(1): ${ }^{1} \mathrm{HNMR}$ spectrum of the $\mathrm{HL}$ ligand in $\mathrm{CDCl}_{3}$.

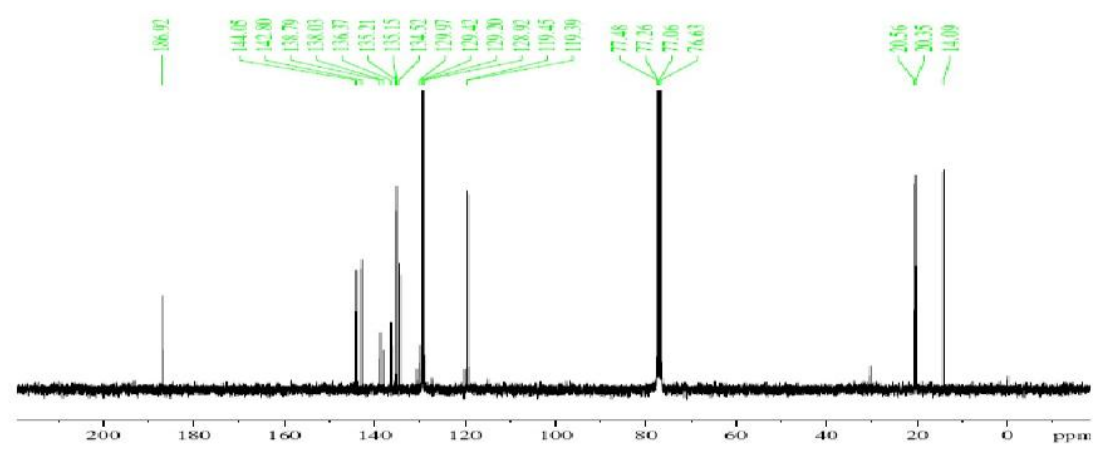

Figure(2): ${ }^{13} \mathrm{CNMR}$ spectrum of (HL) ligand in $\mathrm{CDCl}_{3}$. 


\subsection{Infrared spectra:}

Infrared spectra of Amberlite IR P69 modified with Schiff base (HL) and its metal complexes with $\mathrm{Cr}(\mathrm{III}), \mathrm{Co}(\mathrm{II}), \mathrm{Ni}(\mathrm{II})$ and $\mathrm{Cu}(\mathrm{II})$ ions are shown in figures(3-5). The weak absorptions band appeared in the region $2390-2410 \mathrm{~cm}^{-1}$ may be assigned to the stretching vibration of thiol $-\mathrm{SH}$ groups exhibiting intermolecular hydrogen bonding between $-\mathrm{SH}$ and $\mathrm{C}=\mathrm{N}$ of pyridine and $\mathrm{CH}=\mathrm{N}$ groups ${ }^{(22)}$. The bands obtained at $1380 \mathrm{~cm}^{-1}$ suggest the presence of $-\mathrm{CH}_{2}-\mathrm{CH}$ - bridges. A sharp strong peak at $1630 \mathrm{~cm}^{-1}$ may be ascribed to $\mathrm{C}=\mathrm{N}$ group of the Schiff base, while the strong absorptions at $1490 \mathrm{~cm}^{-1}$ may be attributed to azo $\mathrm{N}=\mathrm{N}$ functional group ${ }^{(23)}$. The presence of $\mathrm{C}-\mathrm{H}$ stretching of aromatic ring may be assigned as a sharp and strong band at $3150 \mathrm{~cm}^{-1}$ which seems to be assigned merged with very broad band of phenolic hydroxy group. Upon complexation, the shifts of $\mathrm{C}=\mathrm{N}, \mathrm{N}=\mathrm{N}$ and $-\mathrm{SH}$ absorptions forward negative region $(20-30) \mathrm{cm}^{-1}$ for all metal chelates indicates the participation of nitrogen atoms of such groups in coordination with $\mathrm{Cr}(\mathrm{III}), \mathrm{Co}(\mathrm{II}), \mathrm{Ni}(\mathrm{II})$ and $\mathrm{Cu}(\mathrm{II})$ ions ${ }^{(24)}$. $\mathrm{As}$ well as the absence of -SHgroup in all spectra of complexes , suggests the deprotonation of Amberlite-IR69 modified resin via complexation with metal ions understudy,figure6. As well as the far-infrared region 400$600 \mathrm{~cm}^{-1}$ show the weak-medium bands related to M-N and M-S respectively, which confirms these formations of metal chelates ${ }^{(25)}$. However the browed bands in the regions $3500-3400 \mathrm{~cm}^{-1}$ in the figure (4-5) may be to crystalline water molecular present in the structure of Amberlite IR P69 and free ligand (HL) thus the absorption were absent in the figure (6)IR spectra of $\mathrm{Cr}(\mathrm{III})$ polymers.Table(2)

Table (2): Infrared spectral data (wave number) $\mathrm{cm}^{-1}$ of the ligand [HL] and its complexes

\begin{tabular}{|c|c|c|c|c|c|c|c|}
\hline Compound & $v(\mathrm{C}=\mathrm{N})$ & $v(\mathrm{SH})$ & $v\left(\mathrm{CH}_{2}-\mathrm{CH}\right)$ & $v(\mathrm{~N}=\mathrm{N})$ & & $v(M-S)$ & Additional band \\
\hline$[\mathrm{HL}]$ & $1630(\mathrm{~s})$ & $2390-2410(w)$ & $\begin{array}{l}1000- \\
900(\mathrm{~m})\end{array}$ & - & - & - & $\begin{array}{l}3003 \mathrm{~m} v(\mathrm{C}-\mathrm{H}) \text { arom. } \\
2900 \mathrm{w} v(\mathrm{C}-\mathrm{H}) \text { aliph }\end{array}$ \\
\hline Ambarlite & $1610(\mathrm{~s})$ & $2200(w)$ & 3150 & $1490(\mathrm{~s})$ & - & - & $\begin{array}{l}\text { 3150m v(C-H) Arom-CH } \\
2970 \mathrm{vw} v(\mathrm{C}-\mathrm{H}) \text { aliph }\end{array}$ \\
\hline $\mathrm{Cr}(\mathrm{Am}) \mathrm{Cl}_{2}$ & $1683(\mathrm{~s})$ & - & $\begin{array}{l}941- \\
1031(w)\end{array}$ & $\begin{array}{c}1419- \\
1475)( \\
w)\end{array}$ & $582^{\mathrm{a}}$ & $553^{\mathrm{b}}$ & \\
\hline $\mathrm{Co}(\mathrm{Am}) \mathrm{Cl}$ & $1660(\mathrm{~s})$ & - & 1030 & $\begin{array}{c}1480(\mathrm{~m} \\
)\end{array}$ & $\begin{array}{l}570^{\mathrm{b}} \\
(\mathrm{w})\end{array}$ & 490(w) & \\
\hline $\mathrm{Ni}(\mathrm{Am}) \mathrm{Cl}$ & $1650(\mathrm{~s})$ & - & $\begin{array}{c}450- \\
1030(w)\end{array}$ & $\begin{array}{c}1469(\mathrm{~m} \\
)\end{array}$ & $\begin{array}{l}570^{\mathrm{a}}( \\
\mathrm{w})\end{array}$ & $490^{\mathrm{b}}(\mathrm{w})$ & $\begin{array}{c}3090 \mathrm{~m}(\mathrm{C}-\mathrm{H}) \mathrm{Ar} \\
2930 \mathrm{w}(\mathrm{C}-\mathrm{H}) \text { aliph }\end{array}$ \\
\hline $\mathrm{Cu}(\mathrm{Am}) \mathrm{Cl}$ & $\begin{array}{c}1640- \\
1588(\mathrm{~s})\end{array}$ & - & $\begin{array}{c}900- \\
1050(w)\end{array}$ & $\begin{array}{c}1471(w \\
)\end{array}$ & $\begin{array}{l}530^{\mathrm{a}}( \\
\mathrm{w})\end{array}$ & $484 b$ & 3064(w) v(C-H) Arom \\
\hline
\end{tabular}

Where $\mathrm{a}=\mathrm{M}-\mathrm{N}, \mathrm{b}=\mathrm{M}-\mathrm{S}$ vibrational modes, $\mathrm{s}=$ strong, $\mathrm{w}=$ weak, $\mathrm{m}=$ medium

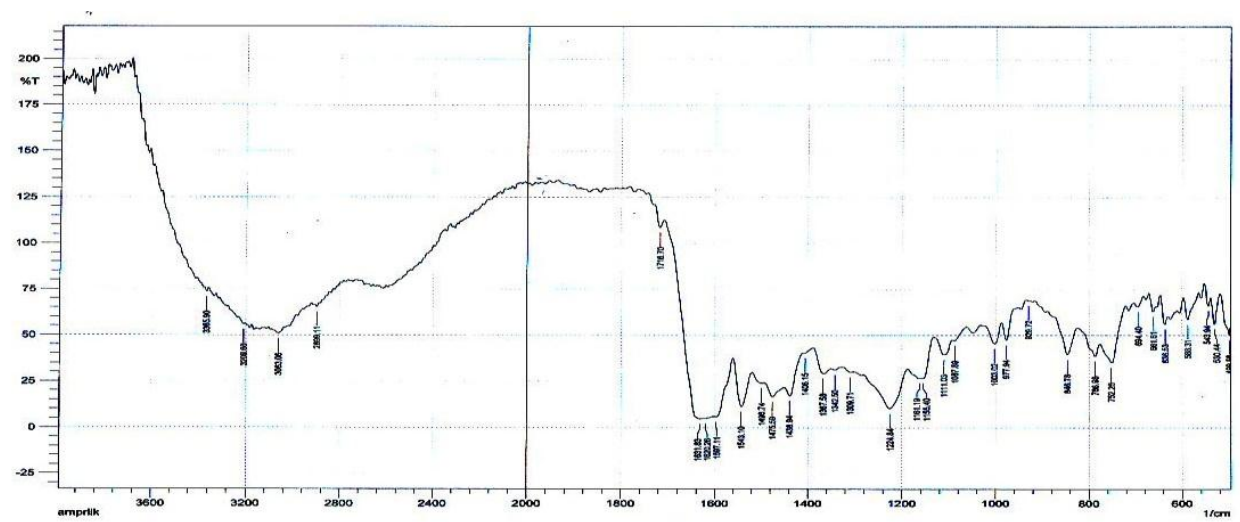

Figure(3)- Infrared spectrum of Amberlite IR P69 


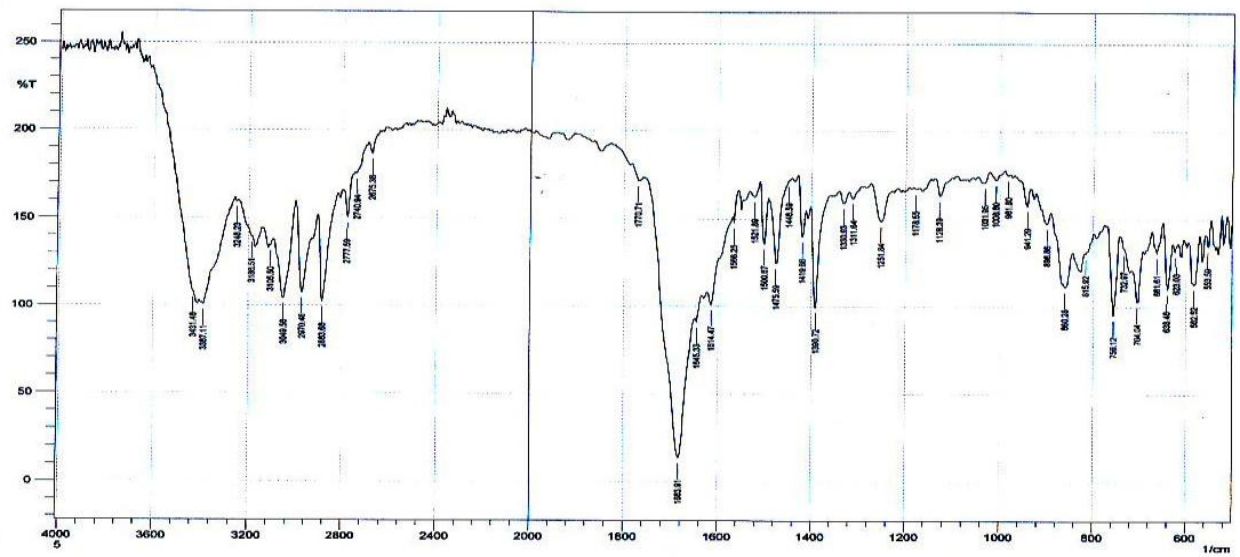

Figure (4)- Infrared spectrum of [HL ]in KBr disc.

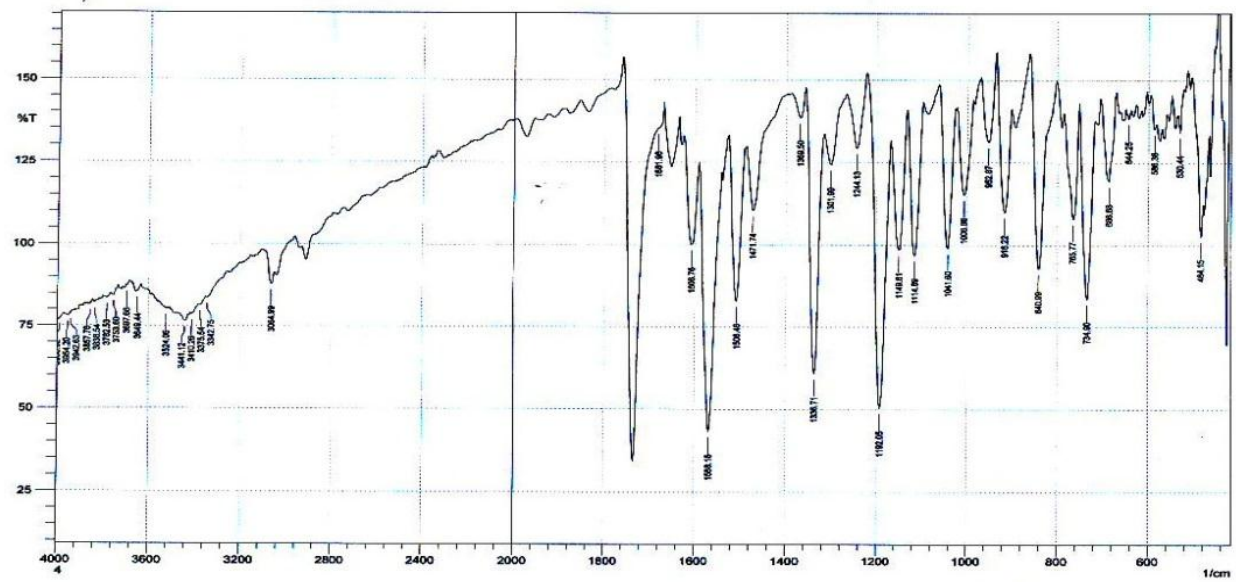

Figure(5) Infrared spectrum of $\mathrm{Cr}(\mathrm{III})$-modified Amberlite in $\mathrm{KBr}$ disc.

3.5-TG-DTA analyses:

The thermal stability of the $\mathrm{Cr}(\mathrm{III})$ and $\mathrm{Cu}(\mathrm{II})$ polymers with the modified Amberlite IR P69 have studied by TG/DTA,figures.(6-7).Thermal curves of $\mathrm{Cr}$ recorded in the range $340-400 \mathrm{C}^{0} \mathrm{Cr}(\mathrm{III})$-chelae has shown in figure(5).total mass loss of chromium(III) chelate is $10.3-15 \%$.The first mass loss has been in range 200$250 \mathrm{C}^{\mathrm{O}}$ with $30 \%$. The last decomposition has been observed in the range $400-450 \mathrm{C}^{0}$ with loss of $\%=33 \%$, thus agree well with the percent's of departures of $\mathrm{Cl}$ ions from the inner-sphere of the $\mathrm{Cr}$ (III) chelates and therefore supports strongly the other data of elemental analyses and spectral data. The decomposition of $\mathrm{Cu}$ (II) polymeric chelates starts with 240 then 280 and $350 \mathrm{C}^{0}$ with expected values of loss $\%$ in the ranges 22,40 and 50 respectively, these fragmentations may be attributed to the calculate loss $\%$ of $\mathrm{Cl}, 2 \mathrm{Cl}$ and formation of $\mathrm{CuO}$ and $\mathrm{CuS}$ compound due to degradation of thiol moiety linked apparently to HLSchiff base ${ }^{(26)}$.

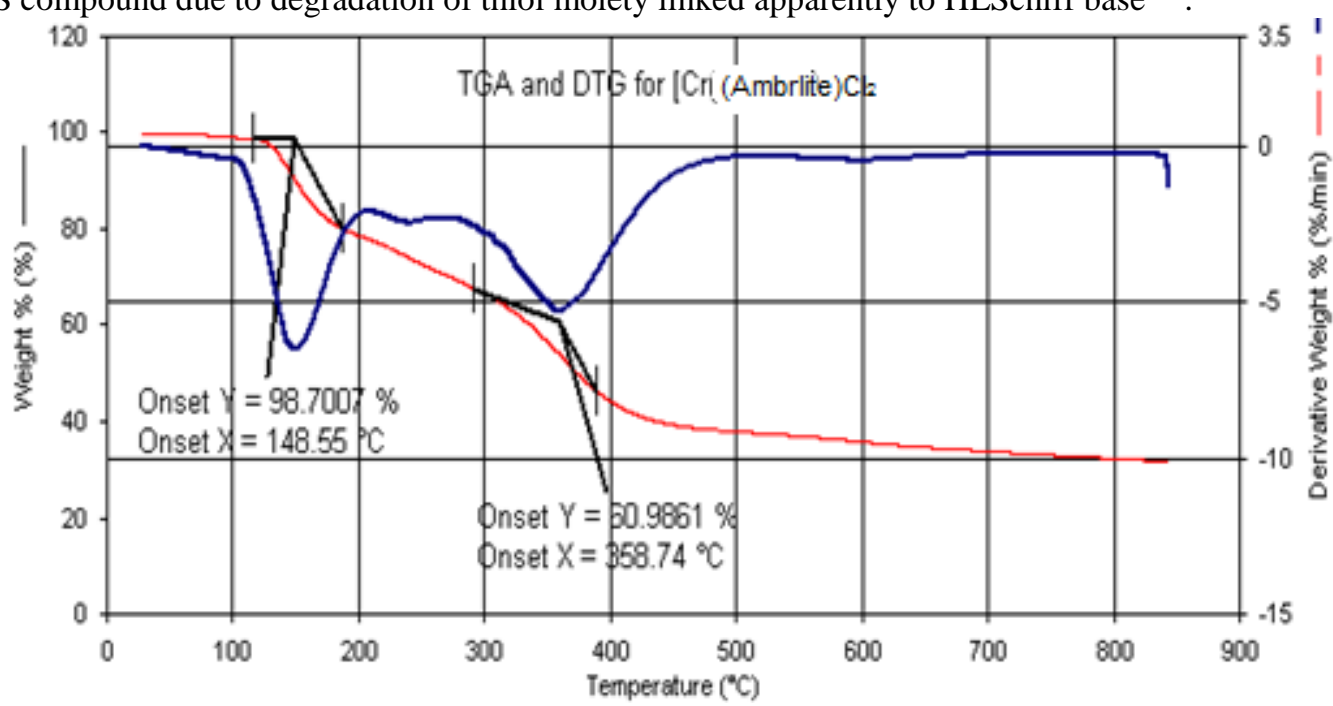

Figure. (6)-TG-DTA of $\mathrm{Cr}$ (III)-Amberlite chelate 


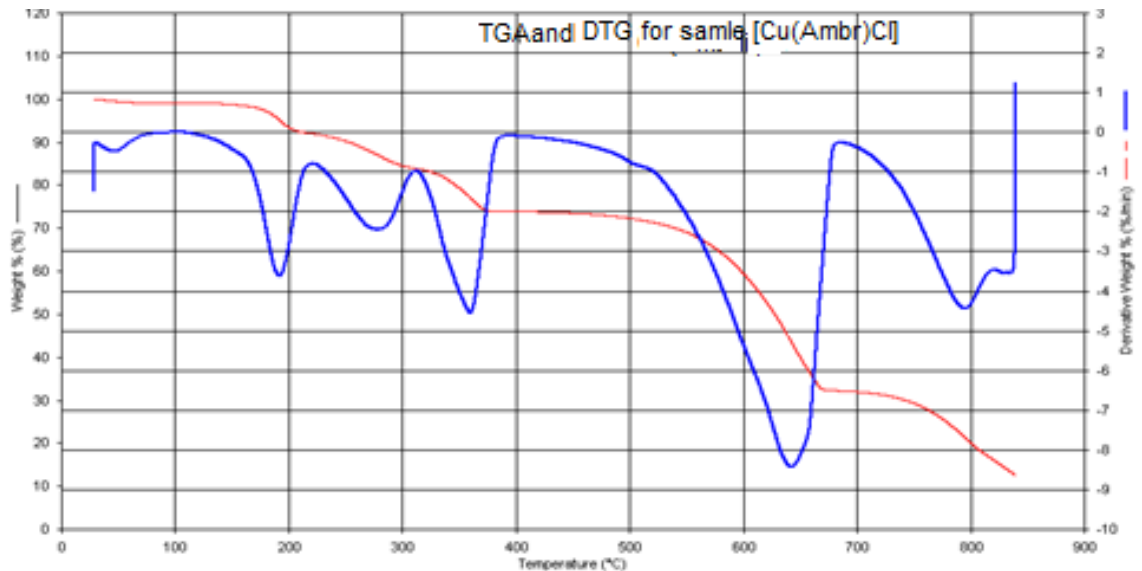

Figure.(7)-TG-DTA of $\mathrm{Cu}(\mathrm{II})$-polymer in $\mathrm{N}_{2}$ atmosphere.

\section{6: Electronic spectra:}

The UV -visible of the modified Amberlite IR P 69 resin and polymeric metal chelate in $\mathrm{DMSO} / \mathrm{CHCl}_{3}$ in pure DMSO were recorded in the range 200-800nm,figures(8-9), these solutions displays two characteristic peaks at 250-270 and 330-365nm. Both of these absorptions seem to be merged with chromophore groups $\mathrm{N}=\mathrm{N}, \mathrm{C}=\mathrm{N}$ which is conjugated with aromatic benzene and pyridine rings ${ }^{(27)}$. The solutions of $\mathrm{Cr}(\mathrm{III}), \mathrm{Cu}(\mathrm{II})$ ,Ni(II) and $\mathrm{Cu}$ (II) chelates in DMSO exhibited new weak bands in the visible region 390-700nm., which may be assigned to $\mathrm{d}-\mathrm{d}^{(28)}$ confirming the formation of metal chelates of such ions with chelating modified resin Amber lite -IR P 69. The figure(10)represents the weak absorption at 671 related to ${ }^{4} \mathrm{~A}_{2} \mathrm{~g} \rightarrow{ }^{4} \mathrm{~T}_{2} \mathrm{~g}$ and $362 \mathrm{~nm}$ that corresponded ${ }^{4} \mathrm{~A}_{2} \mathrm{~g} \rightarrow{ }^{4} \mathrm{~T}_{2} \mathrm{~g}(\mathrm{p})$ confirming octahedral geometry ${ }^{(28)}$. However, the nickel(II) and $\mathrm{Cu}$ (II) complexes solutions of brown to red colors in DMSO records low in testing to peaks at 362 and $670 \mathrm{~nm}$ that related to d-d transition of square planner geometry.However, The cobalt(II) chelate in DMSO shows high Intensity at $311 \mathrm{~nm}$ of $-\mathrm{S} \rightarrow \mathrm{Co}^{+2}$ charge transfer and spin allowed transition at $675 \mathrm{~nm}$ that may be assigned ${ }^{4} \mathrm{~A}_{2} \rightarrow{ }^{4} \mathrm{~T}_{1}$ and ${ }^{4} \mathrm{~A}_{2} \rightarrow{ }^{4} \mathrm{~T}_{1}$ respectively, this support tetrahedral geometry ${ }^{(29)}$.

Table (3):UV-Visible spectra, molar conductance andmagnetic moments of Ambarlite resin and it's suggested structure metal complexes

\begin{tabular}{|c|c|c|c|c|c|c|}
\hline Comp. & $\lambda \mathrm{nm}$ & $\mathrm{cm}^{-1}$ & Assignment & $\Lambda_{\mathrm{m}}^{\mathrm{a}}$ & Propose structure & $\mu$ eff BM \\
\hline $\mathrm{HL}$ & $\begin{array}{l}282 \\
330 \\
270\end{array}$ & $\begin{array}{l}26178 \\
29167 \\
40485\end{array}$ & $\begin{array}{l}\text { C.T } \\
\mathrm{n}-\pi^{*} \\
\pi-\pi^{*}\end{array}$ & - & - & - \\
\hline Ambarlate & $\begin{array}{l}365 \\
315 \\
292\end{array}$ & $\begin{array}{l}27577 \\
31746 \\
34246\end{array}$ & $\begin{array}{l}\text { C..F } \\
\mathrm{n}-\pi^{*} \\
\pi-\pi^{*}\end{array}$ & - & - & - \\
\hline $\mathrm{Cr}(\mathrm{Am}) \mathrm{Cl}_{2}$ & $\begin{array}{l}671 \\
363 \\
324\end{array}$ & $\begin{array}{l}14903 \\
27548 \\
30864\end{array}$ & $\begin{array}{c}{ }^{4} \mathrm{~A}_{2} \mathrm{~g} \rightarrow{ }^{4} \mathrm{~T}_{2} \mathrm{~g} \\
{ }^{4} \mathrm{~A}_{2} \mathrm{~g} \rightarrow{ }^{4} \mathrm{~T}_{1} \mathrm{~g}_{(\mathrm{F})} \\
{ }^{4} \mathrm{~A}_{2} \mathrm{~g} \rightarrow{ }^{4} \mathrm{~T}_{1} \mathrm{~g}_{(\mathrm{p})}\end{array}$ & 19 & Octahedral & 3.40 \\
\hline $\mathrm{Co}(\mathrm{Am}) \mathrm{Cl}$ & $\begin{array}{l}675 \\
324 \\
311\end{array}$ & \begin{tabular}{|l|}
14893 \\
30864 \\
32154 \\
\end{tabular} & $\begin{array}{c}{ }^{4} \mathrm{~A}_{2} \rightarrow{ }^{4} \mathrm{~T}_{1} \\
{ }^{4} \mathrm{~A}_{2} \rightarrow{ }^{4} \mathrm{~T}_{1} \\
\text { C.T }\end{array}$ & 65 & Tetrahedral & 3.9 \\
\hline $\mathrm{Ni}(\mathrm{Am}) \mathrm{Cl}$ & $\begin{array}{l}750 \\
390 \\
250\end{array}$ & $\begin{array}{c}13333 \\
25641 \\
400000\end{array}$ & $\begin{array}{c}{ }^{1} \mathrm{~B}_{1} \mathrm{~g}(\mathrm{~F}) \rightarrow{ }^{1} \mathrm{~B}_{2} \mathrm{~g} \\
{ }^{1} \mathrm{~B}_{1} \mathrm{~g}(\mathrm{~F}) \rightarrow{ }^{1} \mathrm{~A}_{2} \mathrm{~g} \\
\text { C.T }\end{array}$ & 37 & Square planner & 0 \\
\hline $\mathrm{Cu}(\mathrm{Am}) \mathrm{Cl}$ & $\begin{array}{l}671 \\
362 \\
296\end{array}$ & $\begin{array}{l}14903 \\
26490 \\
33783\end{array}$ & $\begin{array}{c}{ }^{2} \mathrm{~A}_{1} \mathrm{~g} \rightarrow{ }^{2} \mathrm{~B}_{1} \mathrm{~g} \\
{ }^{2} \mathrm{~A}_{1} \mathrm{~g} \rightarrow{ }^{3} \mathrm{~B}_{2} \mathrm{~g} \\
\text { C. } \mathrm{T}\end{array}$ & 40 & Square planner & 1.70 \\
\hline
\end{tabular}

C.T $=$ charge transfer, $\mathrm{a}=$ molar conductance in DMSO solution 


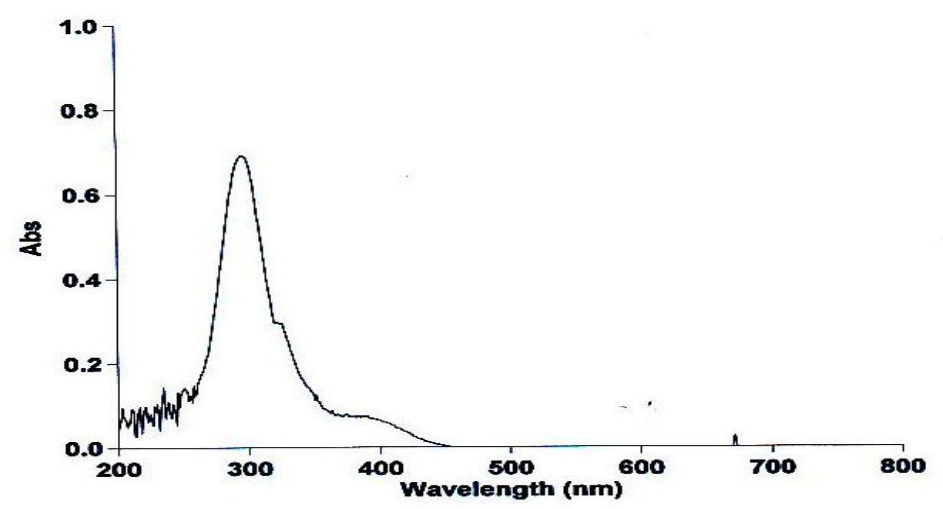

Figure(8)- Electronic spectrum of modified Amb-L in DMSO/CHCl3

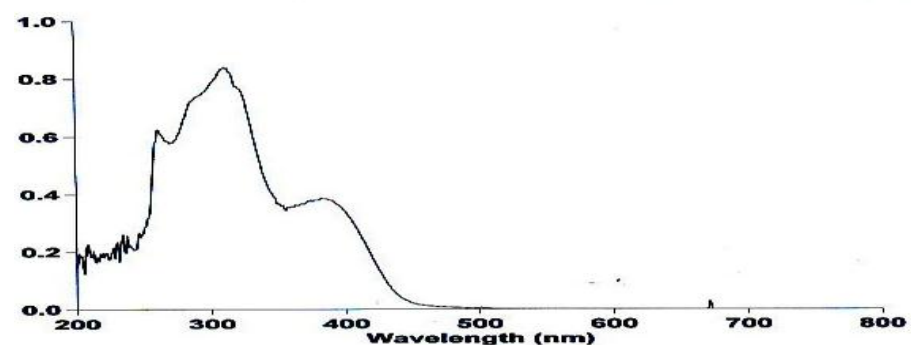

Figure (9)-Electronic spectrum of $\left[\mathrm{Cr}(\mathrm{Am}) \mathrm{Cl}_{2}\right]$ in $\mathrm{DMSO}$

The Conductivity behavior of $\mathrm{Cr}^{(\mathrm{III})}$ chelate in DMSO in the range $60 \mathrm{ohm}^{-1} \mathrm{~cm}^{2} \mathrm{~mol}^{-1}$.suggests the presence of $\mathrm{Cl}^{-1}$ ion in the outer-sphere and agree with the suggested formula.However the $\mathrm{Co}^{\mathrm{II}}, \mathrm{Ni}^{\mathrm{II}}$ and $\mathrm{Cu}^{\mathrm{II}}$ chelates in DMSO shows non -electrolytic behavior showing molar conductance in the range (15-20) $\mathrm{ohm}^{-1} \mathrm{~cm}^{2} \mathrm{~mol}^{-}$ ${ }^{1(30)}$,thus confirmed the proposed structures of polymeric chelates.

\section{Conclusion:}

In this present work, a new modification of Amberlite IR P 69 resin was prepared upon diazoniumcoupling with new Schiff base(5-Methyl-2-\{[(pyridin-2-ylmethyl)-amino]-methyl\}-benzenethiol).Thecoordination behavior of new chelating resin was studies upon azo-coupling has investigated and proved on analysis of FT.IR $,{ }^{1} \mathrm{H},{ }^{13} \mathrm{C}$ NMR,F.T.IR ,UV-visible spectra data and thermal analyses, the coordination linkage of modified Amberlite IR P 69 resin with $\mathrm{Cr}(\mathrm{III}), \mathrm{Co}(\mathrm{II}), \mathrm{Ni}(\mathrm{II})$ and $\mathrm{Cu}(\mathrm{II})$ may be shown in the ${ }^{1} \mathrm{H},{ }^{13} \mathrm{C}$ NMR , FTIR and UVVisble spectroscopy methods. The mentioned identifications besides (C.H.N.M.) Elemental analysis, molar conductance in $\left(\mathrm{CHCl}_{3}\right.$, DMSO $)$, magnetic moments and TG-DTA analysis, suggests the octahedral geometry around $\mathrm{Cr}^{\mathrm{III}}$ ion, square planner around $\mathrm{Ni}^{\mathrm{II}}$ and $\mathrm{Cu}^{\mathrm{II}}$ ions wheas the tetra hydra geometry of high spin was postulated for $\mathrm{Co}^{\mathrm{II}}$ polymeric chelate there structure were shown in schemes (3-4), as below :

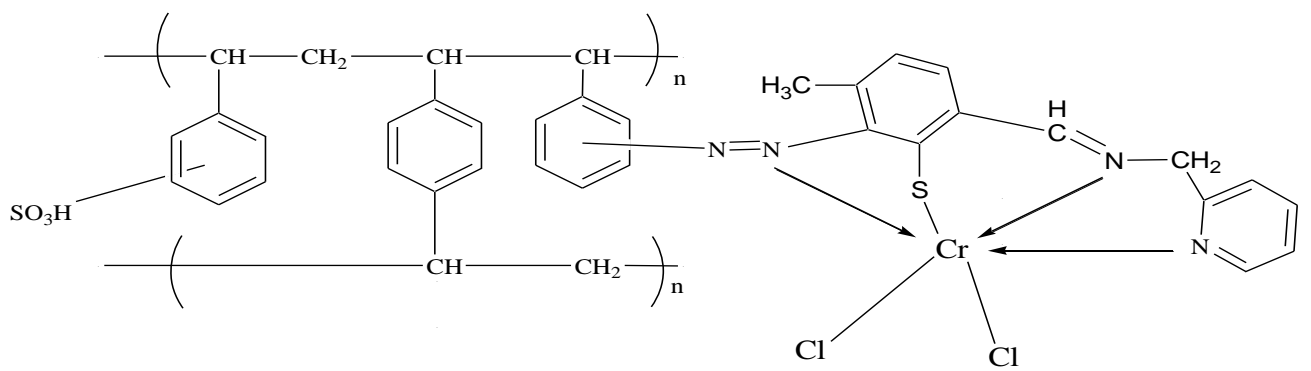

Scheme (3)-Stereo chemical structure of $\mathrm{Cr}$ (III) polymeric chelate. 


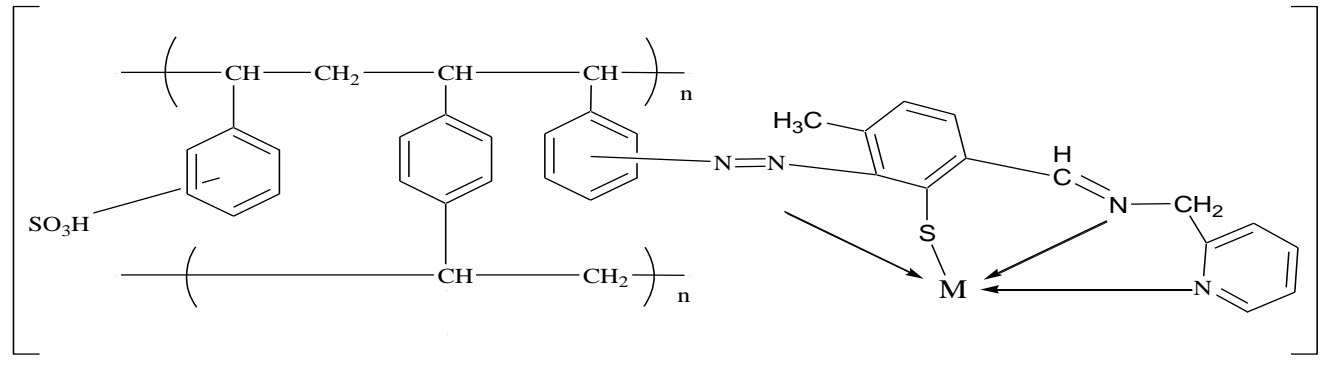

$\mathrm{Cl}$

\section{where $\mathrm{M}=\mathrm{CoII}$, NiII, CuII \\ Scheme(4)- tetrahedral and square planner geometry of $\mathrm{Co}^{\mathrm{II}}, \mathrm{Ni}^{\mathrm{II}}, \mathrm{Cu}^{\mathrm{II}}$ with modified Amberlite IR p64}

\section{References:}

[1]. AmjadHussain, Abdul Ghafoor, M. Anwar-Ul-Haqand Muhammad Nawaz 'Application of the Langmuir and Freundlich Equations for P Adsorption Phenomenon in Saline-Sodic Soils" Materials" Nig.I. Pure \& Appl. (2000) Vol. 15 ,pp.123-130.

[2]. Abdul Sattar Ali Khan “Theory of adsorption equilibria analysis based on general equilibrium constant expression“'Turk J Chem(2012).,36, 219. - 231

[3]. Dada, A.O1, Olalekan, A.P, Olatunya, A.M., DADA, O, Langmuir, Freundlich, Temkin and Dubinin- Radushkevich,“'Isotherms Studies of Equilibrium Sorption of $\mathrm{Zn}^{+2}$ Unto Phosphoric Acid Modified Rice Husk“', IOSR Journal of Applied Chemistry, (2012) 3, Issue 1 PP 38-45.

[4]. Rajesh N.Singru 'Semiconducting and Chelating Applications of newly Synthesized Terpolymer”,

Advances in Applied Science Research, (2011) 2 (6):206-214

[5]. G.Yang,Z.Chen,Z.Zhang,React.Func.Polym. (2002)51,pp.1-6.

[6]. M.M.Jadho. L.J.Paliwal,N.S.Bheve, Ind.J.Chem,(2005).44,542

[7]. P.E.P. Michel ,J.M.Barbe,H.D.Juneja,L.J.Paliwal,Europ. Polym. J. (2007) ,42,. 4995-5000.

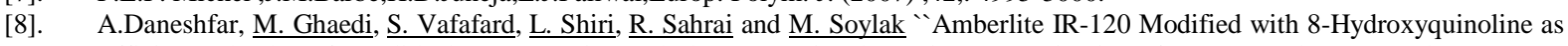
Efficient Adsorbent for Solid-Phase Extraction and Flame Atomic Absorption Determination of Trace Metals, Am J.Polym.,( 2012) 492,pp.240-247.

[9]. M.Reddy,N.Aatika, and M.A.Pasha, “Amberlite IR-120: A reusable catalyst for N-formylation of amines with formic acid using Microwaves“ Chin. J. of Catalysis, (2010) 31(5), pp.518-520.

[10]. B.L.Yule,S.Roberts,J.E.A.Marshall,Org.Geochem.(2000).31,859-870.

[11]. Winterton N. Mechanism of reactions in solution, Annu. Rep. Prog. Chem., Sect. A: Inorg. Chem. (2000) 96, 557-623.

[12]. Shulman A, Dwyer EP. Chelating Agents and Metal Chelates, Academic Press, New York,(1964).

[13]. G.Binzet,H.Arslan,U.Florke,N.Kulku,N.Duran,J.Coordination Chem. (2006) 59,1395-1406.

[14]. R. Jayasekara, I. Harding, I. Bowater, G. B. Y. Christie, and G. T. Lonegram, "Bio modified starch and PVA blended films," Journol of Polymer and the Envirronment,(2003) vol. 11, No. 2, pp. 49-56.

[15]. G.Avsar,N.Kulcu,H.Arslan,Turk.J.Chem. (2002) 26,607-615.

[16]. Lee CH, Kim JS, Suh MY, Lee W. Anal ChimActa (1997) vol.339,pp. 303-312

[17]. B.Bharat,Sankar $\quad$ P.R.,Animesh $\quad$ C. A supramolecularArchitecturesnovelpentacoordinateddioxovanadium(V)salicylaldehyde:Solvent specific crystallization of Dimorphs with contrasting coordination geometries"Eur.J.Inorg.Chem. (2004), pp.1873-1878.

[18]. M. Salvati-Niasari, M. Bazarganipour, M.R. Ganjali and P. Norouzi, Transition Met. Chem., (2007). 32, 9

[19]. Ahmed Barak, P.J.Hell and M.J.Heslop,Reactive\& Functional polymers, (2007) 67,PP:585-600.

[20]. Lee,S.H.,Kim,Shon,J.S.Chung.H.Indus.Eng.J.S., (1999) pp.296-301.

[21]. A.B. Shah, A.V.Shah and M.P. Shah ,Iran ,Polm.J., ,(2006) 1,PP:809-819.

[22]. Silverstein R, WebsterF."spectra photometric Identification of Organic Compound" 6th ed., John Wiley and Son, New York (1998).

[23]. K. Nakamoto, "Infrared and raman spectroscopy for identification of inorganic compounds", $4^{\text {th }}$

[24]. G.Kurt,B.Mercimek,J.Inorg.Organomet.Polym. (2009) 19,pp.367-373

[25]. S.Chandra ,S.Sharma, Transition Met.Chem(2002) 27, p.732.

[26]. T.M.Suzuki,T.Yokoyama,Polyhedron (1984) 3,939.

[27]. A.B.P. Lever, Inorganic Electronic Spectroscopy, Elsevier, Amsterdam (1984).

[28].. Panayotoue T., Dimove T., M. \&Dobervsky, I, Desalinations, (2007) 206 ,pp.135-140

[29]. S. Song, Y. Zhao, M. Zhen, and H. Liang Zhu, Transition Met. Chem., (2012)DoI :10.107.

[30]. W.J.Geary, "The use of molar conductivity for characterization of the coordination compounds in organic solvent", J.Coord.Chem.Rev., (1971) 7,81. 